\title{
MOTYW DROGI W MYŚLI TEOLOGICZNEJ O KOŚCIELE KS. PROF. JANUSZA ST. PASIERBA
}

DOI: http://dx.doi.org/10.12775/TiCz.2021.019

Streszczenie. Artykuł stanowi analizę wybranych publikacji ks. prof. dra hab. Janusza Pasierba ze szczególnym uwzględnieniem homilii wygłoszonej w kościele parafialnym w Żabnie w drugą niedzielę adwentu, 7 grudnia 1986 r. z okazji trzystulecia istnienia tejże świątyni. W pierwszej części przedstawiono treści zawarte w homilii. W drugiej zwraca się uwagę na dane dotyczące ludzi tworzących różnego rodzaju grupy społeczne przebywające na przestrzeni wieków w Żabnie. Ustalenia na ten temat zostają odniesione do obrazu Kościoła rozumianego jako wspólnota ludzi ochrzczonych. W zakończeniu wskazane są wnioski, jakie płyną z nauczania ks. J.S. Pasierba. W podsumowaniu zaakcentowano wyprowadzenie przez kaznodzieję wniosków o charakterze teologicznym z danych historycznych dotyczących dziejów Żabna oraz przybywającej do miasteczka ludności. kultury.

Słowa kluczowe: homiletyka; teologia przepowiadania; historia Polski; teologia

Abstract. The Road Theme in Janusz S. Pasierb's Sermons about the Church. The article analyzes selected writings by Fr. Janusz Stanisław Pasierb, especially the sermon preached in the parish church in Żabno on the second Sunday of Advent, 7 December 1986 - the three-hundredth anniversary of the foundation of that church. The first part of the article presents the contents of the homily. In the second part, attention is paid to data concerning the people who have formed the different social groups residing in Żabno over the centuries. The findings on this subject are related to the image of the Church 
understood as a community of the baptized. The final part of article presents conclusions that come from the teaching of Fr. J. S. Pasierb. The summary emphasizes the fact that the preacher drew theological conclusions from historical data concerning Żabno and the population settling in the village.

Keywords: homiletics; theology of preaching; history of Poland; theology of culture.

Niniejszy artykuł zawiera analizę wybranych kazań, esejów, artykułów oraz wywiadów ks. prof. dra hab. Janusza Stanisława Pasierba. Uczony był teologiem, historykiem sztuki oraz teoretykiem kultury. W uznaniu za swoje badania otrzymał członkostwo w Pontificia Academia Mariana Internationalis. Interesował się sztuką XX wieku, teologią wizualnych i literackich tekstów kultury, dziejami zespołu zabytkowego Pelplina. Pracował jako wykładowca w Seminarium Duchownym Diecezji Chełmińskiej w Pelplinie oraz na Akademii Teologii Katolickiej w Warszawie. Został zapamiętany jako autor kilkunastu monografii, ponad trzystu artykułów naukowych i popularno-naukowych, a także wierszy, esejów, dzienników. Jego literacką spuściznę upamiętnia m.in. zapoczątkowany w 1996 roku coroczny Festiwal Poetycki im. ks. Janusza St. Pasierba w Pelplinie ${ }^{1}$.

Analizowane $\mathrm{w}$ niniejszym artykule teksty zawierają treści wskazujące na uniwersalizm myśli tytułowego uczonego. Tym samym ukazują aktualne i istotne refleksje dla współczesnych kaznodziejów. Stanowią syntezę myśli homilety w zakresie użycia figury „drogi” w refleksjach o Kościele. Niniejsza analiza jakościowa treści wypowiedzi wpisuje się więc w badania o ks. Pasierbie i jego myśli, a także nawiązuje do problematyki z zakresu teologii pastoralnej, zwłaszcza homiletyki oraz teologii przepowiadania.

1 Wybrana literatura przedmiotu o Pasierbie: A. Laddach, Janusz St. Pasierb. Teolog, historyk sztuki, teoretyk kultury, t. 1, Dzieje życia, Toruń 2019, t. 2, Myśl humanisty, Torun 2020; P. Koprowski, Między sacrum i profanum. Biografia intelektualna Janusza Stanisława Pasierba, Pelplin 2015. B. Wiśniewski (red.), Ksiądz Janusz Stanisław Pasierb człowiek dialogu, Pelplin 2015; M. Wilczek (red.), Trwać oznacza ocalić dobro i piękno. Pamięci księdza Janusza St. Pasierba w 15 rocznicę śmierci, Pelplin 2008. 
Pierwsza w niniejszym artykule analizowana wypowiedź duszpasterza została wygłoszona w kościele parafialnym w Żabnie w drugą niedzielę adwentu, 7 grudnia 1986 roku, $\mathrm{z}$ okazji trzystulecia istnienia tejże świątyni². Związek uczonego $\mathrm{z}$ tą niewielką miejscowością znajdującą się na południu Polski jest nieprzypadkowy. Matka Pasierba, Janina Pasierb z domu Tomaszewska, pochodziła właśnie z Żabna. Cała zaś rodzina, tj. matka, ojciec (Jan Kanty Pasierb) oraz ich jedyny syn przetrwali w rzeczonej miejscowości okres II wojny światowej. Później jako młodzieniec oraz dorosły człowiek Pasierb odwiedzał tamtejszą rodzinę, a także okolicznościowo głosił Słowo Boże $\mathrm{e}^{3}$.

Dodatkowe publikacje humanisty - wzmacniające aspekt kazania z Żabna jako wypowiedzi ukazującej motyw drogi w refleksjach uczonego o Kościele - stanowią następujące teksty. Są to: homilie ${ }^{4}$ (z adwentu 1984 r. ${ }^{5}$ z 22 stycznia 1978 r. z kościoła pw. Miłosierdzia Bożego w Warszawie z Mszy za poległych w powstaniu warszawskim ${ }^{6}$, z 6 czerwca $1987 \mathrm{r}$. z wigilii uroczystości Zesłania Ducha Świętego celebrowanej w kościele pw. św. Marcina w Warszawie, a zarazem ze Mszy żałobnej poświęconej Konstantemu Jeleńskiemu ${ }^{7}$, z 11 maja 1991 r. z Mszy św. sprawowanej przy drugim złożeniu prochów Jana Lechonia na cmentarzu w Laskach ${ }^{8}$ ), zapiski ze zbiorów esejów ${ }^{9}$, artykuły (o wizerunku Czarnej Madonny ${ }^{10}$, o kaplicy Matki Boskiej Anielskiej w Warszawie ${ }^{11}$ ), wykład (z 25 czerwca

2 J. Pasierb, Kościół jest droga, „Królowa Apostołów” 51 (1987) 7-8, s. 3-4; te same treści: tenże, Skrzyżowanie dróg, Pelplin 2002, s. 183-190 oraz tenże, Słowo Boże między ludźmi, Katowice 2010, s. 89-94.

3 J. Pasierb, Gałęzie i liście, Pelplin 1993, s. 5-20.

4 Z przyczyn językowych słowa „kaznodzieja/kazanie” i „homileta/homilia” używane są synonimicznie, aby zbyt często nie powtarzać pierwszych terminów.

5 Tenże, Skrzyżowanie dróg, Pelplin 2002, s. 237-249.

6 Tenże, Jezus pogranicza. O poległych w Powstaniu Warszawskim, w: Słowo Boże między ludźmi, Katowice 2010, s. 133.

7 Tenże, Konstanty Jeleński Polak i Europejczyk, „Więź” 31 (1988) 1, s. 51-53; ten sam tekst w: tenże, Słowo Boże, s. 153-156.

8 Tenże, Śniło mi się dziś niebo, „Więź” 34 (1991) 7-8, s. 146-148; ten sam tekst: tenże, Słowo Boże, s. 161-164.

9 Tenże, Skrzyżowanie dróg; tenże, Czas otwarty, Poznań-Warszawa 1972.

10 Tamże, s. 150-152; tenże, Jasnogórska Hodogotria, w: Ikona. Symbol i wyobrażenie, red. E. Bogusz, Warszawa 1984, s. 107-110.

11 Tenże, Warszawski Wieczernik, „Tygodnik Powszechny” (1969) 49, s. 4 
1989 r. wygłoszony podczas odbierania Medalu im. Bernarda Chrzanowskiego Poruszył wiatr od morza ${ }^{12}$ ), autobiograficzne wywiady ${ }^{13}$.

\section{TREŚĆ HOMILII Z ŻABNA}

Koncept wygłoszonej 7 grudnia 1986 roku homilii polegał na przedstawieniu dziejów Żabna i związanych z nim ludzi w odniesieniu do wieloznacznego motywu drogi ${ }^{14}$. Uczony podkreślił, że Kościól jest drogą, a całą swą wypowiedź wkomponował w aktualny okres liturgiczny, tj. adwent ${ }^{15}$.

W początkowych zdaniach kaznodzieja odniósł się do kościoła jako budynku ${ }^{16}$. Przypomniał o pracach wykonanych na rzecz świątyni na przestrzeni lat. Nawę główną zinterpretował jako drogę prowadzącą ze świata do ołtarza, służącą ludziom do przejścia na poszczególnych etapach ich sakramentalnego życia. Kolejno odniósł się do drogi rozumianej jako historia Żabna i jego mieszkańców. Poetycko zauważył, że Kościół przypomina drzewo, a parafie pełnią rolę korzeni, ponieważ umożliwiają

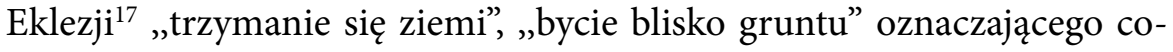
dzienność, powszedniość, zwykłość życia. W tej uwadze teolog zasugerował, że Kościół jest czymś więcej niż wyłącznie instytucją, strukturą hie-

12 Tenże, Część głównego lądu, „Gwiazda Morza” 149 (1989) 16, s. 1 i 4.

13 Tenże, F. Kniotek, Stużę słowu, „Nasza Rodzina” (1979) 1, s. 5; J. Pasierb, [b.t.], w: Czym jest dla mnie Msza święta. Ankieta Duszpasterstwa Środowisk Twórczych $w$ Warszawie, red. W.A. Niewęgłowski, Warszawa 1988, s. 83.

14 Por. tenże, Skrzyżowanie, s. 242. Motyw drogi obecny jest w wielu tekstach literackich i innych dziełach artystycznych, zob. J. Adamowski, K. Smyk (red.), Obrazy drogi w literaturze i sztuce, Lublin 2012; H.U. von Balthazar, Droga krzyżowa w katedrze św. Jadwigi, Katowice 2003; i in.

${ }^{15} \mathrm{O}$ adwencie jako okresie liturgicznym, w którym akcentuje się element drogi i przejścia, zob. G. Matino, Pan nadchodzi! Teologia i liturgia słowa Adwentu i Bożego Narodzenia, Kielce 2009; B. Ogrodowska, Radość wszelkiego stworzenia. Rzecz o adwencie i Bożym Narodzeniu. Historia, tradycja, obyczaj polski, Warszawa 2008; St. Burzawa, Rozwój teologii adwentu, Kraków 1992; i in.

${ }_{16}$ Odniesienie się do kościoła jako budowli w przypadku J. Pasierba wynikało z jego zainteresowań badawczych z zakresu historii sztuki oraz nauczania Kościoła o sztuce sakralnej, zob. A. Laddach, Janusz St. Pasierb, t. 2, Myśl humanisty, s. różne.

17 Słowo „Eklezja” używane jest jako synonim słowa „Kościół” z przyczyn językowych, aby zbyt często nie powtarzać drugiego ze wskazanych pojęć. 
rarchiczną czy motorem rozwoju intelektualnego. Uczony sądził, że do prawidłowego funkcjonowania Eklezji potrzeba bliskości z tym, co oznacza ziemia, a więc z codziennością, pracą, powszechnością, ale i lokalnością; w mocnym osadzeniu w szarej zwykłości, pospolitości wyrażonej nie tylko bywaniem w gronie wysokich sfer, ale przede wszystkim działaniem pośród zwykłych ludzi. W kazaniu Pasierb położył nacisk na elementarne znaczenie istnienia i działania Kościoła na poziomie parafialnym. Sądził, iż ono posiada największy wpływ na kształtowanie wiary ludu Bożego.

Następnie metaforę drogi autor kazania odniósł do obrazu skrzyżowania dróg w sensie geograficznym, a przede wszystkim - metaforycznym. Zdaniem prezbitera, droga poszczególnych ludzi, żabieńskiej parafii oraz całego Kościoła krzyżowała się z innymi symbolicznymi traktami w wyniku wydarzeń historycznych lokalnego oraz globalnego świata. W kontekście tej metafory Pasierb przypomniał słuchaczom homilii wybrane wydarzenia $\mathrm{z}$ przeszłości, np. odnotował przybycie austriackich i rosyjskich wojsk do miasteczka w czasie I wojny światowej ${ }^{18}$. Swoją wypowiedź skończył podsumowującą refleksją na temat Kościoła jako wspólnoty i zarazem kościoła jako świątyni. Ponownie wrócił do metafory drogi, wskazując, iż każdy człowiek związany z kościołem w Żabnie przez jakiś fragment swojego życia kroczył drogą prowadzącą do ołtarza tejże świątyni ${ }^{19}$.

Zapoznanie się treściami przedstawionymi w kazaniu pozwala na wskazanie zawartego tam obrazu żabieńskich mniejszości.

\section{OBRAZ MNIEJSZOŚCl W KONTEKŚCIE OBRAZU KOŚCIOŁA}

Na podstawie treści wygłoszonych przez Pasierba należy zauważyć, iż w homilii uczony zawarł obraz kilku mniejszości w kontekście obrazu Kościoła funkcjonującego w kontekście „skrzyżowań dróg”. Teolog pośrednio przyporządkował członków lokalnej wspólnoty eklezjalnej do społeczności tworzącej większość. Natomiast osoby, które przyjechały do

18 Więcej na temat historii Żabna, zob. A. Tomczyk, Miejsce, Żabno Tuchów 2014; P. Domański, Urbanizacja Żabna w latach 1890-1990, Żabno Tuchów 2010; tenże, Żabno w 2000 roku, Żabno 2008; J. Orlewski, Żabno. 700 lat, Tarnów 1966; i in.

19 J Pasierb, Kościót jest, s. 3-4. 
Żabna w wyniku wydarzeń historycznych zinterpretował jako przedstawicieli mniejszości. Okoliczność spotkania większości z mniejszością nazwał „skrzyżowaniem ich traktów”, tj. losów ich życia w danych realiach historycznych.

Uczony wyodrębnił następujące mniejszości związane z Żabnem: Żydów, protestantów, Szwedów, polskich żołnierzy niepochodzących z Żabna walczących podczas zaborów, I i II wojny światowej, a poza nimi: żołnierzy austriackich, rosyjskich, radzieckich, niemieckich, a także Romów. Wymienione osoby tworzyły mniejszości o charakterze wyznaniowym, narodowym lub pochodzeniowym, a także kulturowym. Można przypuszczać, że większość stanowili mężczyźni. Część z nich przybyła do Żabna jako najeźdźcy, okupanci. Inni byli uciekinierami szukającymi lepszego miejsca do życia. W znacznym stopniu mogli budzić strach wśród stałych mieszkańców miejscowości, związany z przybyciem kogoś nieznanego $^{20}$. Wyjątek stanowiło nadejście wojsk polskich, z którymi wiązano nadzieje w odzyskanie niepodległości.

Stworzony przez Pasierba obraz mniejszości został zestawiony z obrazem Kościoła, tj. synonimem czegoś stałego, niezmiennego świadka historii i ludzi przybywających do miasteczka. Kaznodzieja wskazał na dwa wymiary Kościoła: niebiański (Boży, sakralny, święty) oraz ziemski (ludzki, lokalny i powszechny, grzeszny $)^{21}$. W świetle wypowiedzi uczonego należy zauważyć, iż te dwie sfery (niebiańska oraz ziemska) łączą się właśnie w Kościele, który jest drogą Boga do ludzi i ludzi do Boga. Odbywa się ona w osobowej, indywidualnej relacji człowieka ze Stworzycielem, a także wobec innych ludzi zmierzających drogą ku zbawieniu. Droga ta cechuje się, zdaniem humanisty, pięknem. Ono zaś wpływa na gotowość do poniesienia trudu jej podjęcia. Rzeczone piękno wynika z niebiańskiej tajemnicy Kościoła powszechnego: Misterium opiera się na ludzkich słabościach dźwiganych przez Jezusa Chrystusa i na Jego sakramentach będących pomocą dla człowieka w podążaniu za Mesjaszem.

${ }^{20}$ O kategoriach swojskości i obcości w relacjach międzygrupowych zob. D. Majka-Rostek, Mniejszość kulturowa w warunkach pluralizacji. Socjologiczna analiza sytuacji homoseksualistów polskich, Wrocław 2002, s. 41-48.

21 Por. Katechizm Kościoła Katolickiego (dalej: KKK), Watykan 1992, wyd. pol. II popr., Poznań 2002, nr: 752, 763, 771; por. tamże, nr 772-870. 
Ziemski i niebiański wymiar Kościoła został ukazany w kontekście modelu eklezjalnej wspólnoty, którą tworzą biskupi, księża, wierni; osoby żywe oraz zmarłe; parafianie żyjący na terenie żabieńskiej Parafii, jak i dawni mieszkańcy, którzy wyemigrowali poza jej granice. Wspólnota posiada widzialny i niewidzialny aspekt (wyrażony obecnością zmarłych związanych z Żabnem). Zatem Pasierb w jednym obrazie Kościoła zawarł ludzi należących do wspólnoty eklezjalnej na ziemi tj. Kościoła pielgrzymującego oraz do zmarłych, czyli Kościoła w oczyszczeniu. Kaznodzieja podkreślił duchowy wymiar Eklezji, który nie podlega czasoprzestrzennym granicom ${ }^{22}$.

\section{INNE REFLEKSJE WYKORZYSTUJĄCE MOTYW DROGI W KONTEKŚCIE EKLEZJOLOGICZNEJ MYŚLI J. PASIERBA}

Przedstawione kazanie Pasierba z Żabna nie jest jego jedyną wypowiedzią, w której wybrzmiały treści związane z obrazem Kościoła w drodze. W homilii adwentowej z 1984 r. Pasierb stworzył obraz nadchodzącego Boga i kroczącego przez życie człowieka. Duszpasterz wskazał na obserwowane przez siebie ścieżki postępu, głównie technologicznego. Mówił także o metaforycznych drogach ciągłych wyborów oraz o potrzebie utrzymania duchowego kursu zgodnego $\mathrm{z}$ wiarą. Budowę duchowych dróg rozumiał jako otwieranie perspektyw i pokazanie wyjść $\mathrm{z}$ wewnętrznego pustkowia. Sądził, że zbliżają one Boga do człowieka w sposób delikatny, sugestywny, a nie $\mathrm{w}$ ramach siły i przymusu. J. Pasierb wspomniał też o potrzebie stawania się deptaną, pozornie niedocenioną, niezauważoną drogą poprzez naśladowanie Chrystusa. Głosił, że przyjęcie funkcji traktu komunikacyjnego jest zadaniem każdego człowieka $\mathrm{z}$ osobna, a także całego Kościoła. Coroczne przeżywanie adwentu uznał za możliwość naprawy duchowych ścieżek, odnowienia drogowskazów oraz zadania sobie pytań: jaką drogą jestem dla innych ludzi?; czy zbliżam ich do Boga?; utrudniam czy ułatwiam im spotkanie $\mathrm{z}$ Nim? ${ }^{23}$.

22 J. Pasierb, Kościół jest, s. 3-4.

23 Tenże, Skrzyżowanie, s. 237-249. 
Poza tym w homilii wygłoszonej 22 stycznia 1978 roku ks. Pasierb nauczał, że wspólnota eklezjalna ma być otwarta na wszystkie osoby; winna stać się przestrzenią spotkania ludzi wnętrza i pogranicza Kościoła. Głosił, że paradygmatem spotkania różnych ludzi ma być ich dobra wola, poszukiwanie duchowego światła i ciepła, nie zaś podziały między nimi, czy ateizm ${ }^{24}$. Potwierdzenie tego stanowiska duszpasterz zawarł w zbiorze esejów pod tytułem Skrzyżowanie dróg ${ }^{25}$. W publikacji zawarł opis szeregu spotkań, które świadczą o przecinaniu się geograficznych oraz duchowych traktów uczonego i reprezentantów określonych religii, światopoglądów, środowisk.

Poruszając kwestię drogi w refleksjach o Kościele, ks. Pasierb zaakcentował aspekt wiary. 6 czerwca 1987 roku w wygłoszonym kazaniu podkreślił znaczenie duchowych poszukiwania Chrystusa i zbliżania się do Kościoła. Życie człowieka przedstawił jako złożoną drogę wiary, zapoczątkowaną przyjęciem sakramentu chrztu św., a zakończoną dojściem do ciszy Wieczernika, to znaczy do symbolu Eucharystii ${ }^{26}$.

Analogiczne treści ks. Pasierb zawarł w kazaniu 11 maja 1991 roku. Zdefiniował modlitwę i miłosierdzie jako drogi umożliwiające osiągnięcie komunii człowieka z Bogiem. Nauczał, że zjednoczenie to jest dane każdej osobie. Ona zaś w doświadczeniu relacji ze Stworzycielem odsłania twarz o dwóch symbolicznych wizerunkach: jasnym (publicznym, uczestniczącym w coniedzielnej Mszy św.) i ciemnym (skrywającym ból i samotność ${ }^{27}$. Mimo tego dualistycznego obrazu człowieka duszpasterz wyjaśnił, że Jezus Chrystus jest żywym dowodem realizacji zbawczych planów Boga-Ojca oraz drogą realizacji tych właśnie zamierzeń. Teolog sądził, że obraz Chrystusa jako wyłącznie postaci historycznej, swoiste ,umuzealnienie” Go staje się przyczyną poczucia głębokiej samotności człowieka. Głosił Pana, który jest żywy, obecny i pragnie komunii z każdą osobą ${ }^{28}$.

24 Tenże, Jezus pogranicza, s. 133; por. tenże, Papież w Paryżu, „Więź” 23 (1980) 7-8, s. 24-25.

25 Tenże, Skrzyżowanie.

26 Tenże, Konstanty Jeleński, s. 51-53; ten sam tekst w: tenże, Słowo Boże, s. 153-156.

27 Tenże, Śniło mi się, s. 146-148; ten sam tekst: tenże, Słowo Boże, s. 161-164; por. tenże, Religijność Lechonia, „Tygodnik Powszechny” (1986) 28, s. 1.

28 Tenże, Ta noc, „Tygodnik Powszechny” (1965) 16, s. 11. 
Jako szczególnie ważną drogę człowieka do Jezusa Chrystusa Pasierb wskazał Maryję. Opisując dzieje i teologię wizerunku Czarnej Madonny z Jasnej Góry, wyjaśnił, że obraz był typem ikony zwanym Hodegetria, Hodigetrią oraz Hodigitrią. Wyjaśnił, że słowa te wywiodły się od nazwy kościoła w Ton Hodegon - dzielnicy Konstantynopola. Nazwa wskazanej części miasta odnosiła się do przewoźników, pilotów portowych, przewodników. W związku z tym, według interpretacji Pasierba, w nawiązaniu do ikony z Jasnej Góry Maryję należy określać jako tę, która wskazuje drogę do Chrystusa i wiedzie do Niego ${ }^{29}$.

Pisząc o drodze w kontekście Kościoła, prezbiter zaprezentował także interpretację Drogi Krzyżowej rozumianej na dwa sposoby: jako wydarzenie z życia Jezusa Chrystusa oraz jako ciąg prac ikonograficznych. Mając na uwadze przenikanie się tych dwóch definicji, historyk sztuki podał przykład kaplicy Matki Boskiej Anielskiej z warszawskiego Mokotowa. Szczególną uwagę zwrócił na umieszczone w kaplicy stacje Drogi Krzyżowej, które kończyły się Słonecznym Zmartwychwstaniem. Była to artystyczna praca wskazująca na pokonanie grzechu i śmierci, tj. na radosne wydarzenie nadające sens wszystkim ludzkim klęskom. Autor notatek ocenił kaplicę jako wybitne dzieło współczesnej mu sztuki sakralnej, a zarazem źródło inspiracji do głoszenia soteryjnego zwieńczenia Drogi Krzyżowej Jezusa Chrystusa oraz drogi życia każdego człowieka ${ }^{30}$.

Powyższe treści wskazują na to, że Pasierb rozważał temat drogi w odniesieniu do zagadnienia wiary, soteriologii oraz eklezjologii. Niniejszy temat podjął także w kontekście integracji Polski z Europą. W trakcie przemówienia z 25 czerwca 1989 r. wygłoszonego podczas odbierania Medalu im. Bernarda Chrzanowskiego Pasierb stwierdził, że droga uczestnictwa w kulturze narodu, Europy, jak również całego świata polega na kroczeniu od doświadczenia własnej tożsamości do zrozumienia i współtworzenia specyfiki większych wspólnot ${ }^{31}$. Niniejsza uwaga uczonego znajduje zastosowanie w interpretacji tożsamości Kościoła, którego droga - podobnie jak w przypadku lokalnych i globalnych wymiarów

29 Tenże, Czas, s. 150-152; tenże, Jasnogórska Hodogotria, s. 107-110; por. hasło: hodegetria, w: Słownik terminologiczny sztuk pięknych, red. K. Kubalska-Sulkiewicz, M. Bielska-Łach, A. Manteuffel-Szarota, Warszawa 2003, s. 153.

${ }^{30}$ J. Pasierb, Warszawski Wieczernik, s. 4

31 Tenże, Część głównego lądu, s. 1 i 4. 
kultury - polega na kroczeniu od doświadczeń jednostki, przez funkcjonowanie we wspólnocie rodziny, parafii, diecezji do współkreowania charakteru jednej choć niejednolitej wspólnoty Kościoła powszechnego.

\section{AUTOBIOGRAFICZNA NARRACJA J. PASIERBA O DRODZE W KONTEKŚCIE KOŚCIOŁA}

Jak wskazano powyżej, Pasierb zawarł autorską interpretacje drogi w wybranych kazaniach, artykułach i w przemówieniu. Odrębne notatki zawarł w egodokumentach, tj. autobiograficznych notatkach stanowiących wyraz podzielenia się z czytelnikami najbardziej osobistymi przemyśleniami o własnej drodze wiary ${ }^{32}$.

Przykładem powyższego jest notatka o wstąpieniu do Seminarium Duchownego Diecezji Chełmińskiej w Pelplinie. Próbując wskazać na genezę własnego powołania, humanista stwierdził, iż jego kapłańska droga prawdopodobnie rozpoczęła się w Żabnie u boku tamtejszych dobrych gorliwych księży ${ }^{33}$.

W kontekście własnego kapłaństwa eseista stał na stanowisku, że powołanie każdej osoby wyznacza jej osobistą drogę przez krzyż ku wiecznemu życiu ${ }^{34}$. Omawiając właściwą społeczno-duchową postawę prezbiterów, Pasierb nawiązał do biblijnej sceny z wjazdu Chrystusa na osiołku do Jerozolimy. Teolog uważał, że prezbiter metaforycznie jest tym osiołkiem i nie powinien zasłaniać sobą Zbawiciela ${ }^{35}$. Nauczał, że kapłaństwo staje się adwentem, czyli okresem, podczas którego Jezus przychodzi do ludzi ${ }^{36}$.

Kontynuując autobiograficzną refleksję o osobistej drodze wiary, Pasierb próbował wskazać najważniejsze dla niego Msze św. Wyznał, że

${ }^{32}$ Motyw drogi pojawia się też w poezji Pasierba; zob. A. Kadyjewska, Janusz Stanisław Pasierb: „droga”. Próba interpretacji, w: Janusz St. Pasierb - poeta, red. B. Kuczera-Chachulska, M. Łukaszuk, M. Prussak, Warszawa 2003, s. 61-72.

33 J. Pasierb, F. Kniotek, dz. cyt. s. 5.

34 Tenże, Skrzyżowanie, s. 261-270.

35 Tamże, s. 51.

36 Tamże, s. 62. 
należały do nich te Eucharystie, podczas których zyskiwał wewnętrzną pewność podjętej drogi, tj. wyboru kapłaństwa ${ }^{37}$.

Jako realizację drogi wiary ks. Pasierb wskazał na miłość. Głosił, że stawia ona człowieka w sytuacji duchowej nagości, odsłania go, ukazuje słabości, otwiera, zwłaszcza wobec osoby, którą się kocha i która kocha. Mimo tego dramatycznego duchowego odsłonienia (intencji, uczuć, pragnień, relacji) - w opinii historyka sztuki - miłość jest jedyną drogą poznania świata doczesnego i sakralnego, zrozumienia go oraz integracji z nim. Miłość ukazana jako droga chroni człowieka od śmierci za życia; posiada wybawicielską funkcje, zarówno w porządku wiary i zbawienia, jak również w kontekście relacji społecznych. W opinii humanisty, potwierdzeniem miłości jako drogi ukierunkowanej na zbawienie jest fakt, że wykracza ona poza śmierć; jest wędrówką w celu zwycięstwa grzechu i śmierci - co najdoskonalej ukazał Jezus Chrystus. Natomiast ilustrację miłości jako drogi w kontekście relacji społecznych stanowi sytuacja, gdy w tłumie odnajdują się dwie jedyne dla siebie osoby, fizycznie i duchowo kroczą w swoją stronę, a miłość ocala je od społecznej anonimowości ${ }^{38}$.

\section{WNIOSKI}

Podsumowując powyższe zestawienie wypowiedzi ks. Janusza Pasierba, należy wskazać następujące wnioski. W kazaniu wygłoszonym w 1986 r. w Żabnie homileta zastosował kilka zabiegów oratorskich. Zwrócił uwagę na dzieje miejscowości i tamtejszej świątyni posługując się perspektywą mikrohistoryczną. Osadził historię miejsca wobec wydarzeń i procesów historycznych posiadających europejskie oraz globalne znaczenie. Zastosował kompozycję klamrową, w której początek i koniec wypowiedzi spiął motyw prezbiterium będącego osobistą symboliczną drogą Boga do człowieka oraz człowieka do Boga.

Odnosząc się do dziejów miejscowości, homileta nawiązał do symboliczne „skrzyżowania dróg” przybywających do Żabna przedstawicieli różnych grup społecznych. Naszkicował relacje mniejszości i większości. Nauczał, że indywidualna droga do zbawienia każdego człowieka odbywa

37 Tamże, s. 196; tenże, [b.t.], w: Czym jest, s. 83.

38 Tenże, Słowo Boże, s. 102-115. 
się w rzeczywistości hic et nunc wobec drugiej osoby. Wskazał na wielokulturowość ${ }^{39}$ jako okoliczność do budowania tożsamości m.in. na gruncie wiary ${ }^{40}$. W związku z tym należy zauważyć, iż teolog stworzył schemat opisu jednostki ludzkiej oraz społeczności zmierzającej w kierunku zbawienia. Schemat ten stawia pytanie o relacje jednostek, grup społecznych mniejszości i większości, ludzi różnych wiar i kultur, wspólnoty chrześcijan $\mathrm{w}$ drodze do sacrum. $\mathrm{Z}$ wydarzeń $\mathrm{z}$ przeszłości kaznodzieja wysnuł ponadczasowe wnioski. $Z$ danych historycznych wywiódł konkluzje o charakterze teologicznym; stworzył więc autorską myśl z zakresu teologii historii.

Należy także zauważyć, iż wykorzystując motyw drogi postrzeganej dosłownie oraz symbolicznie (tj. w kontekście relacji społecznych oraz w odniesieniu do duchowej wędrówki ku zbawieniu) teolog był orędownikiem Kościoła otwartego. Sytuował drogę człowieka do świętości w kontekście dialogu z pluralistycznym światem. Jako szczególną inspirację dla ludzi wskazał Matkę Bożą oraz fakt Drogi Krzyżowej kończącej się Zmartwychwstaniem. Głosił, że droga ta dotyczy każdego człowieka, ale nie odbywa się w oderwaniu od codziennej rzeczywistości i jej uczestników. Jako część indywidualnej drogi osoby do świętości wskazał uczestnictwo w Kościele, a w ramach tego: relację do siebie, trójosobowego Boga i każdego człowieka, bez względu na to, czy jest on członkiem jakiejś społecznej większości czy mniejszości.

Przedstawione powyżej treści dowodzą zatem, że w motywie drogi Pasierb zawarł ideę jedności budowanej w różnorodności jednostek oraz grup. Był orędownikiem pokojowej, otwartej współegzystencji, spotkania, komunikacji. W prowadzeniu ludzi do zbawienia akcentował subtelność i otwartość formy głoszenia Ewangelii. Sugestywnie stwierdził, że katechizacja, jak również obecność Eklezji w kulturze „nie może być wciąganiem za włosy do kapliczki, ale ukazywaniem najgłębszej jedności wszystkiego,

39 Por. J. Paczocha, b.t., w: Publikacja materiałów konferencji na temat „,Wielokulturowość - problem czy bogactwo, red. D. Berlińska, T. Schäpe, Gliwice 1994, s. 18; A. Kożyczkowska, K. Kossak-Główczewski, Polityka wielokulturowości jako otwieranie przestrzeni możliwości, w: Mniejszości etniczne. Dylematy i konteksty tożsamościowe, red. A. Kożyczkowska, K. Kossak-Główczewski, Gdańsk 2014, s. 7-12; A. Lusińska, Społeczna komunikacja pomiędzy mniejszościami a społeczeństwem polskim, czyli rzecz o komunikowaniu tego, co ważne, w: Mniejszości etniczne, s. 57-64.

40 Por. KKK, nr 142-184. 
co świat znaczy. Chcąc coś pokazać, trzeba zachować się dyskretnie, stanąć nieraz na uboczu. To wcale nie jest pozbawione sensu, że znaków drogowych nie umieszcza się na środku drogi" ${ }^{41}$ [wyróżn. - A.L.]. Ze względu na scharakteryzowane powyżej cechy Pasierb został zapamiętany jako człowiek dialogu ${ }^{42}$, a jego myśl przyczyniła się m.in. do powstania Fundacji Pionowy Wymiar Kultury. Instytucja ta została założona w 2014 r. w Toruniu. Jej celem, zgodnie $\mathrm{z}$ refleksją J. Pasierba, stało się m.in. interpretowanie wiary jako drogi poszukiwań.

\section{BIBLIOGRAFIA}

Adamowski J., Smyk K. (red.), Obrazy drogi w literaturze i sztuce, Lublin 2012.

Burzawa S.T., Rozwój teologii adwentu, Kraków 1992.

Domański P., Urbanizacja Żabna w latach 1890-1990, Żabno-Tuchów 2010.

Domański P., Żabno w 2000 roku, Żabno 2008.

Kadyjewska A., Janusz Stanisław Pasierb: „droga”. Próba interpretacji, w: Janusz St. Pasierb - poeta, red. B. Kuczera-Chachulska, M. Łukaszuk, M. Prussak, Warszawa 2003, s. 61-72.

Katechizm Kościoła Katolickiego, Watykan 1992, wyd. pol. II popr., Poznań 2002.

Koprowski P., Między sacrum i profanum. Biografia intelektualna Janusza Stanisława Pasierba, Pelplin 2015.

Kożyczkowska A., Kossak-Główczewski K., Polityka wielokulturowości jako otwieranie przestrzeni możliwości, w: Mniejszości etniczne. Dylematy i konteksty tożsamościowe, red. A. Kożyczkowska, K. Kossak-Główczewski, Gdańsk 2014, s. 7-12.

Laddach A. Janusz St. Pasierb. Teolog, historyk sztuki, teoretyk kultury, t. 1, Dzieje życia, Toruń 2019.

Laddach A. Janusz St. Pasierb. Teolog, historyk sztuki, teoretyk kultury, t. 2. Myśl humanisty, Toruń 2020.

Lusińska A., Społeczna komunikacja pomiędzy mniejszościami a społeczeństwem polskim, czyli rzecz o komunikowaniu tego, co ważne, w: Mniejszości etniczne. Dylematy i konteksty tożsamościowe, red. A. Kożyczkowska, K. Kossak-Główczewski, Gdańsk 2014, s. 57-64.

Majka-Rostek D., Mniejszość kulturowa w warunkach pluralizacji. Socjologiczna analiza sytuacji homoseksualistów polskich, Wrocław 2002.

${ }^{41}$ J. Pasierb, Pisane w kamieniu, „Tygodnik Powszechny” (1970) 40, s. 4

42 B. Wiśniewski (red.), Ksiądz Janusz Stanisław Pasierb człowiek dialogu, Pelplin 2015. 
Matino G., Pan nadchodzi! Teologia i liturgia słowa Adwentu i Bożego Narodzenia, Kielce 2009.

Ogrodowska B., Radość wszelkiego stworzenia. Rzecz o adwencie i Bożym Narodzeniu. Historia, tradycja, obyczaj polski, Warszawa 2008.

Orlewski J., Żabno. 700 lat, Tarnów 1966.

Paczocha J., b.t., w: Publikacja materiałów konferencji na temat ,, Wielokulturowość - problem czy bogactwo, red. D. Berlińska, T. Schäpe, Gliwice 1994, s. 17-19.

Pasierb J., b.t., w: Czym jest dla mnie Msza święta. Ankieta Duszpasterstwa Środowisk Twórczych w Warszawie, red. W.A. Niewęgłowski, Warszawa 1988, s. 82-84.

Pasierb J., Czas otwarty, Poznań-Warszawa 1972.

Pasierb J., Część głównego lądu, „Gwiazda Morza” 149 (1989) 16, s. 1 i 4.

Pasierb J., Gałęzie i liście, Pelplin 1993.

Pasierb J., Jasnogórska Hodogotria, w: Ikona. Symbol i wyobrażenie, red. E. Bogusz, Warszawa 1984, s. 107-110.

Pasierb J., Konstanty Jeleński Polak i Europejczyk, „Więź” 31 (1988) 1, s. 51-53.

Pasierb J., Kościół jest droga, „Królowa Apostołów” 51 (1987) 7-8, s. 3-4.

Pasierb J., Papież w Paryżu, „Więź” 23 (1980) 7-8, s. 24-25.

Pasierb J., Pisane w kamieniu, „Tygodnik Powszechny” (1970) 40, s. 4

Pasierb J., Religijność Lechonia, „Tygodnik Powszechny” (1986) 28, s. 1.

Pasierb J., Skrzyżowanie dróg, Pelplin 2002.

Pasierb J., Słowo Boże między ludźmi, Katowice 2010.

Pasierb J., Śniło mi się dziś niebo, „Więź” 34 (1991) 7-8, s. 146-148.

Pasierb J., Ta noc, „Tygodnik Powszechny” (1965) 16, s. 11.

Pasierb J., Warszawski Wieczernik, „Tygodnik Powszechny” (1969) 49, s. 4.

Pasierb J., Kniotek F., Słuzę słowu, „Nasza Rodzina” (1979) 1, s. 4-7.

Tomczyk A., Miejsce, Żabno Tuchów 2014.

von Balthazar H.U., Droga krzyżowa w katedrze św. Jadwigi, Katowice 2003.

Wilczek M. (red.), Trwać oznacza ocalić dobro i piękno. Pamięci księdza Janusza St. Pasierba $w 15$ rocznicé śmierci, Pelplin 2008.

Wiśniewski B. (red.), Ksiądz Janusz Stanisław Pasierb człowiek dialogu, Pelplin 2015. 